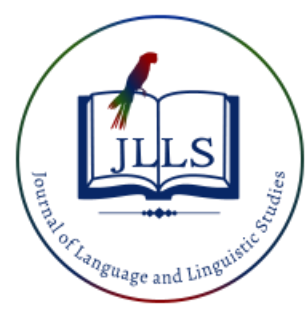

Available online at www.jlls.org

JOURNAL OF LANGUAGE AND LINGUISTIC STUDIES

ISSN: 1305-578X

Journal of Language and Linguistic Studies, 17(3), 1175-1183; 2021

\title{
Takarir: A new simultaneous translator voice to text to promote bi/multilinguality
}

\author{
M. Kharis a ${ }^{\text {ID }}$, Kisyani $^{b}$ iD , Suhartono $^{c \text { iD }}$, Yuniseffendri ${ }^{\text {ID }}$ \\ ${ }_{a, b, c, d}$ Universitas Negeri Surabaya, Indonesia \\ APA Citation: \\ ${ }^{a}$ Universitas Negeri Malang, Indonesia
}

Kharis, M., Kisyani., Suhartono., Yuniseffendri. (2021). Takarir: A new simultaneous translator voice to text to promote bi/multilinguality. Journal of Language and Linguistic Studies, 17(3), 1175-1183. Doi: 10.52462/j1ls.83

Submission Date:30/03/2021

Acceptance Date:20/06/2021

\begin{abstract}
This study aims to evaluate Takarir as the product of the research development reviewed from the look and the results of its translation. This is a qualitative descriptive type of research. Data are obtained from students of German learners who understand translation theory and have the skills of the German language at least B1 level standards the common European framework of reference for languages (CEFR). Takarir is an application of a web-based translation machine and supports 44 input languages and dialects. Takarir is built with Macromedia Dreamweaver software. Respondents followed the seminars in German and Bahasa Indonesia, activated the Takarir as a translator, and observed its translation results. The analysis results show that the Takarir can translate speech to text from Bahasa Indonesia to German and vice versa with several errors. Based on the analysis, it can be concluded that Takarir takes advantage of the new technology, inspires to learn, and supports bi/-multilingualism activities.
\end{abstract}

Keywords: simultaneous translation machine; bi-/multilingual; Takarir; languages; voice to text

\section{Introduction}

The COVID-19 pandemic has succeeded in shaping a society that is closer to the digital world. Many educational institutions have adopted online learning to continue educational activities during the COVID-19 pandemic (Sharma et al., 2020). Both national and international conference activities are carried out online with a conference application. Especially in international conferences, participants and presenters with less foreign language skills experience difficulties following and delivering material in foreign languages. In an international situation like this, a machine translator (hereafter abbreviated as MT) is needed that can translate simultaneously and produce an acceptable translation.

Currently, many MT applications have been developed, both based on Android and desktop. However, there are still not many MTs that can work simultaneously. In simultaneous MT, an application must determine when to display the translation, given that the word input is carried out continuously. One of the models used is the neural machine translation (NMT) model, which can make decisions when providing input and when to produce translated text (Wilken et al., 2020). However,

\footnotetext{
${ }^{1}$ Corresponding author.

E-mail address: m.kharis.fs@um.ac.id
} 
much-developed software that uses this method is not published, so that the wider community cannot use it.

Related to the description above, the research development by Kisyani et al. produced the TAKARIR product, which is an MT web-based (.html) application that can work simultaneously (Kisyani et al., 2020). Takarir was developed by utilizing MT GT as the dataset, Takarir as MT application is designed to promote bi/multilingualism at international conferences. The purpose of developing this application is to assist participants and presenters in following the conference material. Given that MT GT has advantages and disadvantages, Takarir's research products need to be evaluated, later as input for improvement, both in terms of layout (appearance) and the ability of the Takarir in translating text.

\subsection{Literature Review}

The use of machine translation has become widespread, for example, google translate (hereinafter abbreviated as GT). In learning, the use of GT by students has aspects of vocabulary, aspects of grammar, and aspects of spelling. Chandra and Yuyun's research shows that the highest use of GT is used at the vocabulary level, followed by phrases as the second highest, and sentences as the third. Spelling is the fourth highest used, while grammar is the least used among students (Sönmez, 2019). It was also found that GT is considered a dictionary because students use GT mostly in understanding vocabulary items (Chandra \& Yuyun, 2018).

In addition, many studies show that foreign language students often consult GT. Ducar's research highlights this technology's strengths and limitations, exploring 21st-century pedagogical solutions designed to take advantage of MT capabilities and alternative technologies (Ducar \& Schocket, 2018). Meanwhile, Murtisari's research revealed the use of MT in teaching English as a Foreign Language (EFL) in terms of the length of the text translated by students and their perceptions of MT. Murtisari's research examined EFL students' attitudes towards the use of MT in reading and writing text tasks (Murtisari et al., 2019).

\subsection{Research Questions}

Based on the background of the description, these research questions can be formulated as follows:

1. How is the performance of Takarir in terms of appearance?

2. How is the performance of the Takarir in terms of the aspect of the translation results?

\section{Method}

To answer the first question, the researchers, with all their knowledge, evaluate the Takarir from the viewpoint of appearance. Quantitative data were obtained from a questionnaire about the performance. The researchers used the percentage descriptive analysis technique to process the data obtained through a questionnaire with the percentage formula. To determine the conclusions, then the criteria set by Kuswandi were used according to the table of validity levels below.

Table 1. Conversion Rate of Validity

\begin{tabular}{|c|c|}
\hline Percentage & Information \\
\hline $86 \%-100 \%$ & A. Very good \\
\hline $71 \%-85 \%$ & B. Good \\
\hline $56 \%-70 \%$ & C. Pretty good \\
\hline$<55 \%$ & D. Not good \\
\hline
\end{tabular}


Cumulatively, if the results obtained to reach the criteria above $71 \%$, the media developed is considered to have adequate/positive validity values and can be stated fit for use (Kuswandi, 2001).

To answer the second research question, twelve respondents attended seminars in German and Indonesian using Takarir as a simultaneous translation tool. The respondents were students majoring in the German language at Universitas Negeri Malang who had taken the course Übersetzung (Translation) and had German language skills at least level B1 standard Gemeinsamer Europäische Referenzrahmen (GER). In this study, the data collected was limited to only translating the Indonesian input with the German output and vice versa. The instrument used was in the form of open and closed questionnaires to determine the respondent's opinion about the Takarir application as an MT application in terms of the aspects of the translation results.

\section{Results}

\subsection{Description of Takarir}

Kisyani's research and development product has produced Takarir, which is a web-based online MT application. Thus, Takarir can be accessed by all operating systems (OS), Windows, Android, and Mac. Takarir's development is done using Macromedia Dreamweaver software. Takarir can be accessed via the https://takarir.tp.ac.id/ and it is free. Even so, the use of Takarir, for the time being, is limited only for UNESA students, evidenced by the ownership of the sso.unesa.ac.id account. After going through registration, the user is waiting for verification from the developer. If the user has been verified, the user can log in. Takarir's view is shown in the following figure:

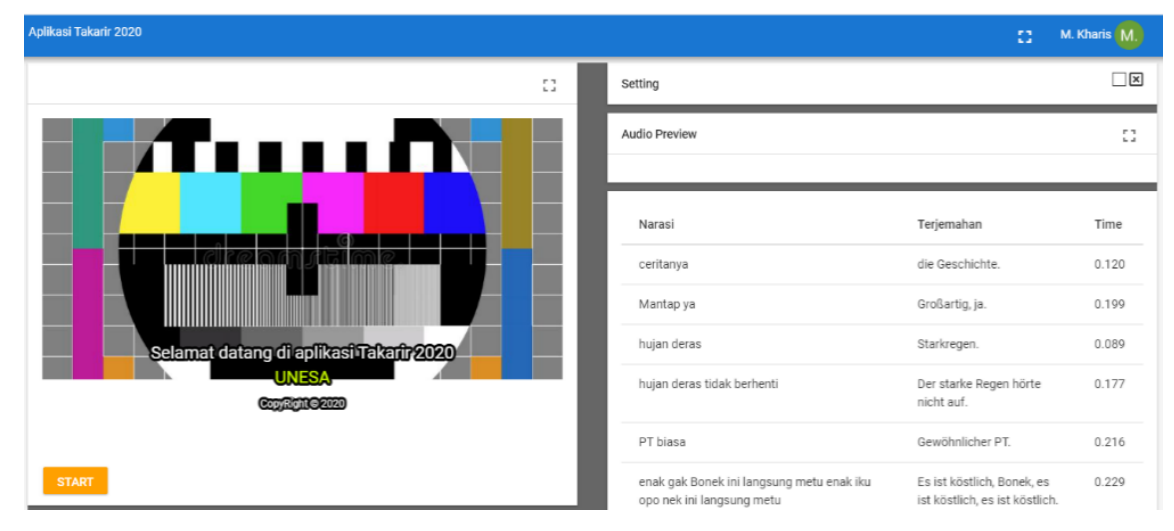

Figure 1. Takarir's view

Takarir has 44 languages and dialects input support. Of the 44 languages, six languages have a choice of various dialects, as shown in the table below:

Table 2. Number of dialect variations

\begin{tabular}{lcc}
\hline No & Languages & Available dialects \\
\hline 1. & Arabic & 9 \\
2. & English & 7 \\
3. & Espanol & 20 \\
4. & Italiano & 2 \\
5. & Português & 2 \\
6. & Chinese & 4 \\
\hline
\end{tabular}

There are four panels displayed by the Takarir: video panel, settings, audio preview, and output. The video panel displays the presenter's picture as well as the subtitles of the entered voice captions. The settings panel contains input and output language settings, microphone input, and camera input. 
From 44 input languages, Takarir provides options into 22 external languages. To select the input language, the user clicks on the Bahasa yang Anda ucapkan (Language you speak) menu. The output panel contains a narration menu that displays a transcription of the user's voice input. The better the quality of the voice that is entered, the less potential for Takarir to make transcription errors. In narrating the voice, the user has the choice of using audio input, namely through Default Microphone, Communication Microphone, or Microphone. Transcription errors can result in translation errors being generated. The button 'Terjemah' (English: Translation) displays the translation results based on the transcription in the 'narasi' menu. The 'Time' menu shows how long it takes to translate the entered voice text. Briefly, the process of translating Takarir is shown in the following chart:

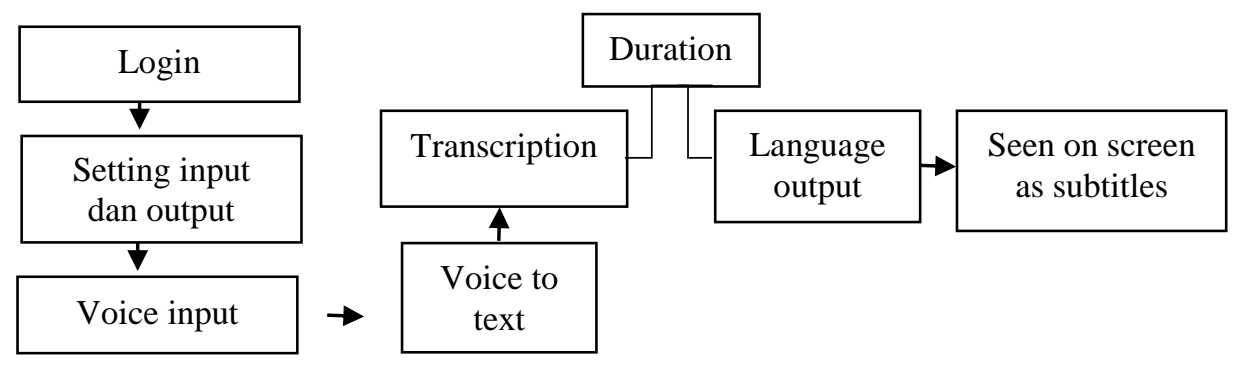

Figure 2. A process of translation by Takarir

Unfortunately, the operating instructions are still written in a mixture of Bahasa Indonesia and English. The operating language and its meaning in English are shown in the following table:

Table 3. Instructions in Bahasa Indonesia

\begin{tabular}{lll}
\hline No & \multicolumn{1}{c}{ Instructions } & \multicolumn{1}{c}{ In English } \\
\hline 1. & Selamat datang di aplikasi Takarir 2020 & Welcome to Takarir 2020 \\
2. & Bahasa yang Anda ucapkan & Language you speak/ input \\
3. & Dialek bahasa & Dialects \\
4. & Keluaran bahasa & Output language \\
5. & Narasi & Transcription \\
6. & Terjemahan & Translation \\
\hline
\end{tabular}

Researchers used Takarir in trials and not in seminars. Based on these trials, the researchers know the features available and tried the product in various ways and inputs. Researchers as users outside the team conducted Takarir evaluations using a questionnaire as shown in the table below:

Table 4. Questionnaire about product aspects

\begin{tabular}{|c|c|c|c|c|c|c|}
\hline \multirow{2}{*}{ No. } & \multirow{2}{*}{ Questions } & \multicolumn{4}{|c|}{ Score } & \multirow[t]{2}{*}{ Why did you give that score? } \\
\hline & & 1 & 2 & 3 & 4 & \\
\hline 1. & Ease of using the product & & & $\mathrm{x}$ & & $\begin{array}{l}\text { It only has four panels, so the menu looks } \\
\text { clear. }\end{array}$ \\
\hline 2. & Navigation usage & & & $\mathrm{x}$ & & Quite clear \\
\hline 3. & Button consistency & & & & $\mathrm{x}$ & Not many buttons \\
\hline 4. & Use of type and font size & & & & $\mathrm{x}$ & Clear \\
\hline 5. & Composition and color combinations & & & $\mathrm{x}$ & & Only two basic colors \\
\hline 6. & Use of sound effects & & $\mathrm{x}$ & & & There is no back sound. \\
\hline 7. & Use of narration / clues & & $\mathrm{x}$ & & & $\begin{array}{l}\text { instructions for use are only available in } \\
\text { the desc tool }\end{array}$ \\
\hline 8. & Display quality ( screen design ) & & & $\mathrm{x}$ & & Quite clear \\
\hline 9. & Voice input sensitivity & & & $\mathrm{x}$ & & It depends on mic quality and sound input. \\
\hline 10. & Voice to text identification speed & & & & $\mathrm{x}$ & There is a delay, but still reasonable. \\
\hline 11. & The ability to detect punctuation & & $\mathrm{x}$ & & & Speakers need to pronounce the \\
\hline
\end{tabular}


marks

12. Support choice of language input

punctuation. and output

Score

$\begin{array}{llll}0 & 6 & 15 & 16\end{array}$

To process the questionnaire data above, the researchers used the formula:

$$
\text { Percentage }=\frac{\sum(0+6+15+16)}{12 \times 4} \times 100 \%=84
$$

Cumulatively, the results obtained have reached a value of 84 , so that the Takarir product is considered to have a good validity value and is suitable for use (Kuswandi, 2001).

\subsection{Questionnaire Results}

To get data on the language aspect, respondents attended seminars in German and in Bahasa Indonesia. The speaker's speech in the seminar is entered into the Takarir system. Data on the language aspect is only limited to the first five minutes of the seminar to get an idea of Takarir's ability to translate text from German to Indonesian and vice versa. After attending the seminar for approximately five minutes, the respondents filled out a questionnaire, as shown in the table below:

Table 5. Questionnaire on aspects of the German - Indonesian translation

\begin{tabular}{|c|c|c|c|c|c|}
\hline \multirow{2}{*}{ No. } & \multirow{2}{*}{ Question Points } & \multicolumn{4}{|c|}{ Score } \\
\hline & & 1 & 2 & 3 & 4 \\
\hline 1. & $\begin{array}{l}\text { Translation results are reviewed } \\
\text { from accuracy }\end{array}$ & 8 & 8 & 33 & 50 \\
\hline 2. & results in terms & 8 & 8 & 33 & 50 \\
\hline 3. & $\begin{array}{l}\text { Translation results in } \\
\text { of naturality }\end{array}$ & 0 & 41 & 33 & 25 \\
\hline
\end{tabular}

In the German language seminar, the respondents activated the Takarir and looked at the results of the translation in Bahasa Indonesia. On the aspect of accuracy, half of the respondents stated that the translation results were accurate, especially on the word-to-word translation. The results of the translation into Indonesian are following the German-language text. The results of the translation can be understood well with good word order. Every word in a source language (SL) is translated with a synonym that is appropriate and meaningful together with the target language (TL). A small proportion of respondents argued that the word-to-word translation was more or less correct and did not match the meaning in the source language. In the aspect of clarity, half of the respondents believed that Takarir could have a clear and correct translation, appropriate to the context, and there is no mistranslation. Thus, the result of the translation can be understood. A small proportion of respondents thought that the translation results were unclear; Takarir did not appropriately translate the daily conversation. Thus, the translated text was not under the TL structure. In the naturality aspect, nearly half of respondents believe that the translation of Takarir is less common/reasonable because it translated word-to-word, so it seemed uncommunicative. Even though the translation results can still be understood, for TL readers the text is not naturally comfortable to read because the sentence structure sided to SL. In some parts, it is not quite right when viewed from the reasonableness of the target language. Only a quarter of respondents thought that the translated text could be understood. 
Table 6. Questionnaire on aspects of Indonesian - German translation

\begin{tabular}{clllll}
\hline \multirow{2}{*}{ No. } & \multicolumn{1}{c}{ Question } & \multicolumn{4}{c}{ Score } \\
\cline { 3 - 6 } & 1 & 2 & 3 & 4 \\
\hline 1. & $\begin{array}{l}\text { Translation results are reviewed } \\
\text { from accuracy }\end{array}$ & 0 & 16 & 41 & 41 \\
2. & $\begin{array}{l}\text { Translation results in terms } \\
\text { of clarity } \\
\text { Translation results in terms } \\
\text { of } \text { naturality }\end{array}$ & 8 & 8 & 33 & 50 \\
3. & 8 & 25 & 41 & 25 \\
\hline
\end{tabular}

In the Indonesian language seminar, the respondents activated the Takarir and looked at the results of the translation in German. Almost half of the respondents think that the translation results are correct on the aspect of accuracy, translated word-to-word. Every word is translated correctly and has the same meaning in LT. In general, the choice of words and grammar is accurate, although some words do not match SL's meaning. On the aspect of clarity, half of the respondents thought that the Takarir could produce a precise translation following the SL text's contents. Thus, the results of the translation can be well understood. However, a third of respondents found sentence structure in the translated text is more minor under LT, particularly sentences with the language of daily conversation. On the aspect of naturality, almost half of the respondents thought that the translation of Takarir is less common/reasonable because Takarir seemed to use translation word-toword. Although the translation results can still be understood, the translation results are less comfortable to read because the sentence structure is in favor of the SL and gives an unnatural impression. Only a quarter of respondents think that Takarir can provide translation results that are reasonable and easy to understand.

\section{Discussion}

Takarir is an application that can be used to assist bilingualism activities in seminars, especially international seminars. Takarir works using GT as MT. Although many research results show that many GTs are still not perfect, this feature can help at least international seminar participants. Currently, GT has become the MT most widely used by students. The most reasons for using GT are that it is free, saves time, and is always equipped with the latest data.

The translation results of Takarir were accurate, especially on the word-to-word translation. This could help the students as seminar participants to understand the seminar material. The use of computers half students to develop a positive attitude after they are taught the benefits of using computer-aided translation tools (Çetiner, 2018). However, the translation results of Takarir have not fully produced translated texts that are accurate, clear, and natural, even though GT is currently the largest machine translation in the world with 109 languages. In this study, the differences in the translation results of the Takarir are more due to differences in the type and quality of the user's microphone. The different lexical could harm the result of the translation (Omar \& Gomaa, 2020). As explained earlier, the translation results of Takarir depend on the quality of the input because Takarir is an MT based on the voice-to-text translation method.

Many studies have considered the use of MT GT as research material. For example, the results of Ghasemi \& Hashemian's research show that active/passive sentence errors are the most frequent errors in the Persian-English translation results (Ghasemi \& Hashemian, 2016). Ismail and Hartono's research revealed GT's weakness in translating English News text into Indonesian. Ranks of most common errors to those least found in the data, namely errors in grammar, terminology, syntax, translation/misconceptions, literals/fidelity, punctuation, ambiguity, capitalization, and spelling. The data findings show that translation errors are caused by the GT statistical method, GT's inability to 
understand the context of the text outside the sentence, and errors in the source language text (Ismail \& Hartono, 2016). Meanwhile, Rahmannia \& Triyono revealed that the GT translations' results were often incorrect, or there were several errors. Error analysis always occurs in grammar and inaccurate word choice. The dominance of translation errors occurred in deviations of meaning (Rahmannia \& Triyono, 2019), which were also experienced by respondents when using Takarir.

MT systems' statistical approach such as GT still leaves many linguistic problems in the translation results in terms of accuracy, clarity, and naturality. Awadh revealed that MT had poor translation and couldn't able to achieve accurate translation (Awadh \& Khan, 2020). To improve the translation results' quality, there must be an increase in the corpora, both in terms of quantity, coverage, and quality. In terms of quantity, there must be an increase in data and an expansion of the data domain. In quality, the data source language translation's accuracy to the target language must be improved (Meilawati \& Nursanti, 2018). Technology must be integrated into human life because the technology supports daily life and improves teaching and learning, and simplifies aspects of life in various fields, including in the activities of the translation of scientific papers (Yao, 2017) oral presentation. One of the critical components of translator professionalism is digital competence, closely related to the digital environment (Gavrilenko, 2020). Making Takarir by utilizing MT is a form of digital competence implementation. The dynamics of digital processes require continuous updating of digital competencies to create appropriate knowledge and skills in translation activities' learning process (Gavrilenko, 2020). The use of Takarir in international conferences is an activity to implement digital competencies. Currently, existing MT still requires human resources to produce better translations (Halimah, 2018) because MT's errors might mislead the students in the simultaneous interpreting practice (Qin \& Wang, 2020). With this, MT merely a tool that can help translate. Users must be more able to consider the translation results in terms of accuracy, clarity, and naturality.

\section{Conclusions}

The use of technology is an integral functional part of life. Students can take advantage of the power of new technology in a campus environment and be inspired to learn and support multilingualism activities, such as international conferences. Based on this research it can be concluded that Takarir as an MT application has several advantages, although the results of its translation still require considerations of human resources.

\section{References}

Awadh, A., \& Khan, A. S. (2020). Challenges of translating neologisms comparative study: Human and machine translation. Journal of Language and Linguistic Studies, 16(4), Article 4. https://www.jlls.org/index.php/jlls/article/view/1798

Çetiner, C. (2018). Analyzing the attitudes of translation students towards cat (computer-aided translation) tools. Journal of Language and Linguistic Studies, 14(1), 153-161.

Chandra, S. O., \& Yuyun, I. (2018). The Use of Google Translate in EFL Essay Writing. LLT Journal: A Journal on Language and Language Teaching, 21(2), 228-238.

Ducar, C., \& Schocket, D. H. (2018). Machine translation and the L2 classroom: Pedagogical solutions for making peace with Google translate. Foreign Language Annals, 51(4), 779-795. https://doi.org/10.1111/flan.12366

Gavrilenko, N. (2020). Digital Competence is the Key Component of Professionalism of the Translator. Journal of Talent Development and Excellence, 12(3s), 08-15. 
Ghasemi, H., \& Hashemian, M. (2016). A Comparative Study of "Google Translate" Translations: An Error Analysis of English-to-Persian and Persian-to-English Translations. English Language Teaching, 9(3), 13-17.

Halimah, H. (2018). Comparison of Human Translation with Google Translation of Imperative Sentences in Procedures Text. BAHTERA : Jurnal Pendidikan Bahasa Dan Sastra, 17(1), 11-29. https://doi.org/10.21009/BAHTERA.171.2

Ismail, A., \& Hartono, R. (2016). Errors Made In Google Translate in the Indonesian to English Translations of News Item Texts. ELT Forum: Journal of English Language Teaching, 5(2), Article 2. https://doi.org/10.15294/elt.v5i2.11228

Kisyani, K., Sumarno, A., Yustanti, W., \& Suhartono. (2020). Pengembangan Takarir dalam Masa Pandemi Covid-19 [Laporan Akhir Penelitian Guru Besar]. Universitas Negeri Surabaya.

Kuswandi, D. (2001). Validasi Media: Analisis Kelayakan Media yang Akan Dikembangkan. Bahan Kuliah tidak diterbitkan. Malang: Jurusan TEP FIP UM.

Meilawati, A., \& Nursanti, E. (2018). Identifikasi Kesalahan terhadap Hasil Terjemahan Mesin Bahasa Inggris ke Bahasa Jawa: Kajian Semantik. Diksi, 26(2), 88-92. https://doi.org/10.21831/diksi.v26i2.25446

Murtisari, E. T., Widiningrum, R., Branata, J., \& Susanto, R. D. (2019). Google Translate in Language Learning: Indonesian EFL Students' Attitudes. The Journal of Asia TEFL, 16(3), 978-986. https://doi.org/10.18823/asiatefl.2019.16.3.14.978

Omar, A., \& Gomaa, Y. A. (2020). The Machine Translation of Literature: Implications for Translation Pedagogy. International Journal of Emerging Technologies in Learning (IJET), 15(11), 228-235.

Qin, Y., \& Wang, C. (2020). Can Machine Translation Assist to Prepare for Simultaneous Interpretation? International Journal of Emerging Technologies in Learning (IJET), 15(16), 230237.

Rahmannia, M., \& Triyono, S. (2019). A Study of Google Translate Translations: An Error Analysis of Indonesian-to-English Texts. International Journal of Linguistics, Literature, and Translation (IJLLT), 2(3). https://doi.org/10.32996/ijllt.2019.2.3.22

Sharma, K., Deo, G., Timalsina, S., Joshi, A., Shrestha, N., \& Neupane, H. C. (2020). Online Learning in the Face of COVID-19 Pandemic: Assessment of Students' Satisfaction at Chitwan Medical College of Nepal. Kathmandu University Medical Journal, 18(2), 40-47. https://doi.org/10.3126/kumj.v18i2.32943

Sönmez, H. (2019). Review of studies focused on bilingualism. Journal of Language and Linguistic Studies, 15(3), 1045-1068.

Wilken, P., Alkhouli, T., Matusov, E., \& Golik, P. (2020). Neural Simultaneous Speech Translation Using Alignment-Based Chunking. ArXiv:2005.14489 [Cs]. http://arxiv.org/abs/2005.14489

Yao, S. (2017). Application of Computer-aided Translation in English Teaching. International Journal of Emerging Technologies in Learning (IJET), 12(08), 105-117.

\section{AUTHOR BIODATA}

Kharis, $\mathbf{M}$ is now Ph.D. student at Universitas Negeri Surabaya Indonesia, Jl. Lidah Wetan, Lidah Wetan, Kec. Lakarsantri, Kota SBY, Jawa Timur 60213 Indonesia. He is Assoc. Prof and lecturer for the German language in 
the German Department, Universitas Negeri Malang, Indonesia, Jl. Semarang 5, Malang 65145. He teaches the courses German as a Foreign Language at various levels.

Kisyani is Professor for Bahasa Indonesia at Universitas Negeri Surabaya Jl. Lidah Wetan, Lidah Wetan, Kec. Lakarsantri, Kota SBY, Jawa Timur 60213 Indonesia. She is a researcher in the field digital learning and bi/multilingualism in teaching and learning.

Suhartono is now Head of Postgraduate Department Language and Literature Education at Universitas Negeri Surabaya Jl. Lidah Wetan, Lidah Wetan, Kec. Lakarsantri, Kota SBY, Jawa Timur 60213. He's interested in research about Language Teaching and Learning.

Yuniseffendri is now a lecturer of the Postgraduate Department Language and Literature Education at Universitas Negeri Surabaya J1. Lidah Wetan, Lidah Wetan, Kec. Lakarsantri, Kota SBY, Jawa Timur 60213 Indonesia. He's interested in researches about Language Teaching and Learning. 